\section{Climate Change: Observed Impacts on Planet Earth}

\author{
Edited by Trevor M. Letcher \\ Elsevier, 2009 \\ [ISBN: 044453301X; ISBN 13: 9780444533012$]$
}

Climate Change can be considered as a sequel to Trevor Letcher's recent book Future Energy (published in 2008, also by Elsevier). The two are inexorably linked.

The book is divided into 25 chapters, each one written by an expert in the field. The first five chapters focus on the possible causes of climate change, while in particular the first chapter deals with the possible effects of anthropogenic greenhouse gases. Chapter six discusses the geological history of climate change, and puts the whole idea of climate change into perspective. The remaining 19 chapters focus on a variety of global changes brought about by climate change. These include detailed scientific observations on weather patterns; plants and plant pathogens; lichens; bird, insect, and animal ecology; sea temperature and ocean currents; rising sea levels; and coastal erosion and ice sheets. If there ever was doubt about whether global and climate changes are taking place, these chapters may help put such thinking to rest.
This book supports the work done by the Intergovernmental Panel on Climate Change through experimental evidence. There has been no speculation, through computer modeling, at predicting possible future scenarios. The book is a scientific presentation of the facts surrounding climate change and no attempt has been made to offer solutions, although the basic nature of the problem is obvious; the burning of oil, coal, and gas is causing a significant rise in atmospheric carbon dioxide, water vapor, nitrogen oxides, and particulate matter-all of which influence our climate. This book should have a strong influence on deciding our future energy options.

IUPAC supports the book, through its Chemistry and the Environment Division. IUPAC's adherence to the International System of Quantities is reflected in the book, with the use of SI units wherever possible.

Climate Change is a source book and guide and is written, not only for students and researchers and their professors, but for decision makers in government and in industry, journalists and editors, corporate leaders, and all interested people who wish for a balanced, scientific, and honest look at this major problem facing us.

www.iupac.org/web/ins/2007-050-2-600

\section{Ecosystem Change and Human Well- Being-Research and Monitoring Priorities Based on the Findings of the Millennium Ecosystem Assessment}

\section{ICSU-UNESCO-UNU (2008), Paris, International Council for Science}

The Millennium Ecosystem Assessment (MA) was called for by the United Nations Secretary-General Kofi Annan in 2000. Initiated in 2001, the objective of the MA was to assess the consequences of ecosystem change for human well-being and the scientific basis for action needed to enhance the conservation and sustainable use of those systems and their contribution to human well-being. The MA has involved the work of more than 1360 experts worldwide. Their findings, contained in five technical volumes and six synthesis reports, provide a state-of-the-art scientific appraisal of the condition and trends in the world's ecosystems and the services they provide (such as clean water, food, forest products, flood control, and natural resources) and the options to restore, conserve, or enhance the sustainable use of ecosystems.

The bottom line of the MA findings was that human actions are depleting Earth's natural capital, putting such strain on the environment that the ability of the planet's ecosystems to sustain future generations can 